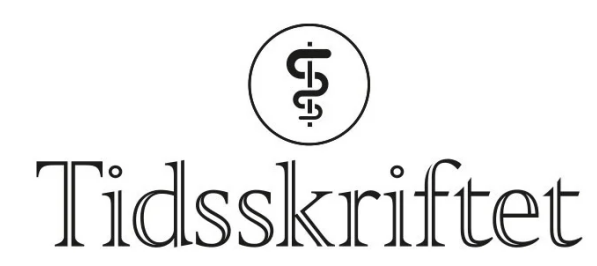

DEN NORSKE LEGEFORENING

\title{
Nye anbefalinger for kolorektalscreening
}

MEDISINSK NYTT

\section{ERLEND HEM}

Email: erlend.hem@medisin.uio.no

Tidsskriftet

\section{Amerikanske retningslinjer begrenser screening for kolorektalcancer til personer under 76 år.}

U.S. Preventive Services Task Force anbefalte i 2002 kolorektalscreening av alle over 50 år. Nå har man systematisk gjennomgått litteraturen for å oppdatere anbefalingene (1). I de nye retningslinjene anbefales screening av personer i aldersgruppen 50-75 år, ingen screening av personer over 85 år og individuell vurdering av personer i alderen 76-84 år. Det mangler dokumentasjon for å vurdere risiko forbundet med de nyere fecesundersøkelser for blod og undersøkelser med virtuell koloskopi. De anbefaler også gjentakelse av koloskopi hvert tiende år, av sigmoidoskopi hvert femte år eller av konvensjonelle fecesundersøkelser for blod hvert år.

- Screening for eldre personer er omdiskutert, da den naturlig forventede levealder kan være kortere enn den forventede tiden med forebyggende effekt av screening. Eldre har dessuten mer komorbiditet som fører til økt fare for komplikasjoner ved screeningprosedyren, sier lege Michael Bretthauer ved Medisinsk avdeling, Rikshospitalet.

- Kunnskapsgrunnlaget for denne oppdateringen er imidlertid stort sett det samme som for de forrige retningslinjene. Mens forfatterne tidligere har unnlatt å uttale seg om screening av eldre personer, har man nå kommet til at det ikke foreligger tilstrekkelig nytteverdi av slik screening for personer over 75 år. Disse nye anbefalingene bringer dermed ikke noe fundamentalt nytt, men gjenspeiler et skritt i retning av en mer nøktern holdning til kunnskapsgrunnlaget for kolorektalscreening.

- Anbefalingene for screening av yngre personer er imidlertid også i stor grad bygd på svakt kunnskapsgrunnlag. Mange europeiske og nordiske eksperter, meg inkludert, vil derfor fortsatt være kritiske til disse amerikanske anbefalingene. Det mangler randomiserte studier for alle screeningtester, unntatt for okkult blod i avføring, sier Bretthauer. 
LITTERATUR

1. U.S. Preventive Services Task Force. Screening for colorectal cancer. Ann Intern Med 2008; 149: 62737 .

Publisert: 15. januar 2009. Tidsskr Nor Legeforen. DOI: 10.4045/tidsskr.08.0629

(C) Tidsskrift for Den norske legeforening 2023. Lastet ned fra tidsskriftet.no 26. april 2023. 